\title{
PENGARUH SIKAP DAN KEMAMPUAN AKSES INTERNET TERHADAP HASIL BELAJAR KIMIA PESERTA DIDIK SMA NEGERI 6 KUPANG
}

\author{
MARSELINUS TIKA \\ SMA Negeri 6 Kupang \\ e-mail:marcel.tika@gmail.com
}

\begin{abstract}
ABSTRAK
Tujuan dari penelitian adalah untuk mengetahui pengaruh sikap dan kemampuan akses internet terhadap hasil belajar Kimia peserta didik.Penelitian ini merupakan penelitian kuantitatif, menggunakan metode survei.Survei dilakukan pada sampel berjumlah 104 orang peserta didik kelas XII MIPA SMANegeri 6 Kupang. Pengumpulan data dilakukan dengan pemberian kuesioner dan dengan melaksanakan test hasil belajar Kimia. Hasil penelitian menunjukkan bahwa variabel sikap pada mata pelajaran kimia dan kemampuan akses internet untuk media pembelajaran online secara bersama-sama memiliki pengaruh yang signifikan terhadap hasil belajar kimia peserta didik. Hal ini ditunjukkan oleh koefisien determinasi $\mathrm{R}^{2}=0,790$ dengan nilai uji constant $(0,470)$. Sementara uji masing-masing koefisien regresi variabel sikap pada mata pelajaran kimia diperoleh koefisien regresi sebesar $(0,496)$ dan variabel kemampuan akses internet (0,516). Dari hasil tersebut diperoleh kesimpulan bahwa sikap dan kemampuan akses internet untuk media pembelajaran online secara bersama-sama memiliki pengaruh yang signifikan terhadap hasil belajar Kimia peserta didik.
\end{abstract}

Kata Kunci: Sikap, Kemampuan Akses Internet, Hasil Belajar Kimia

\section{ABSTRACT}

The purpose of the study was to determine the effect of attitudes and internet access abilities on students' learning outcomes in Chemistry. This research is a quantitative study, using a survey method. The survey was conducted on a sample of 104 students of class XII MIPA SMA Negeri 6 Kupang. The data was collected by giving a questionnaire and by carrying out a test of chemistry learning outcomes. The results showed that the attitude variables in chemistry subjects and the ability to access the internet for online learning media together had a significant influence on students' chemistry learning outcomes. This is indicated by the coefficient of determination $\mathrm{R} 2=0.790$ with a constant test value $(0.470)$. While the test of each regression coefficient of the attitude variable in chemistry subjects obtained a regression coefficient of (0.496) and the variable of internet access ability (0.516). From these results, it can be concluded that the attitudes and abilities of internet access for online learning media together have a significant influence on students' learning outcomes of chemistry.

Keywords: Attitude, Internet Access Ability, Chemistry Learning Outcomes

\section{PENDAHULUAN}

Pandemi Covid-19 memaksa kebijakan social distancing, atau di Indonesia lebih dikenalkan sebagai physical distancing (menjaga jarak fisik) untuk meminimalisir persebaran Covid-19. Kementerian Pendidikan dan Kebudayaan (Kemdikbud) merespon dengan kebijakan belajar dari rumah melalui pembelajaran daring. Hal ini kemudian diimplementasikan dalam media pembelajaran berbasis E-Learning di sekolah, termasuk di SMA Negeri 6 Kupang.

Sejak awal 2019, kegiatan belajar mengajar di kelas mulai dibatasi dan kelas online dimulai. Respon siswa terhadap pembelajaran online terus menjadi perhatian guru dan bidang kurikulum sekolah, karena hal ini sangat menentukan efektivitas belajar dan capaian hasil belajar peserta didik. Sudjana (2005) menyatakan bahwa hasil belajar siswa pada hakikatnya adalah perubahan tingkah laku dan sebagai umpan balik dalam upaya memperbaiki proses belajar mengajar. Tingkah laku sebagai hasil belajar dalam pengertian luas mencakup bidang kognitif, afektif dan psikomotorik. 
Sikap merupakan item penting dalam menentukan hasil belajar siswa, yang perlu selalu dijaga dan ditingkatkan. Akan tetapi kenyataannya, prestasi belajar peserta didik pada mata pelajaran Kimia masih rendah.Peserta didik (siswa) pada tingkat awal Sekolah Menengah Atas sering dihinggapi oleh kesan sulitnya pelajaran kimia, sehingga mempengaruhi prestasi belajar. Bagi sebagian peserta didik ilmu kimia adalah pelajaran yang membosankan karena mempelajari materi yang dianggap abstrak (Rosa, 2015).

Slameto (2003) menyatakan bahwa untuk menjamin hasil belajar yang baik, maka peserta didik harus memiliki sikap terhadap bahan yang dipelajarinya. Apabila bahan pelajaran tersebut tidak menjadi perhatian peserta didik, maka akan timbul kebosanan, sehingga berdampak pada keengganan untuk belajar.Sikap yang baik idealnya akan mendukung proses pembelajaran, baik itu online maupun offline. Penelitian Rosa (2015) memiliki kesimpulan bahwa sikap pada mata pelajaran kimia dan konsep diri berpengaruh terhadap prestasi belajar kimia siswa.

Selain sikap, kemampuan siswa dalam mengakses internet cukup mempengaruhi keaktifan KBM secara daring. Penelitian Ismail (2017) menemukan bahwa terdapat pengaruh penggunaan internet terhadap hasil belajar IPS peserta didik kelas X SMK Nurul Huda Sukaraja OKU Timur. Hal ini menjadi rujukan penting jika dikaitkan dengan pola pembelajaran online yang gencar dilakukan sejak pandemi Covid-19. Pembelajaran kemudian serentak membutuhkan akses internet baik oleh guru maupun siswa.Berdasarkan hasil survei awal yang dilakukan, $65 \%$ dari 50 siswa yang diwawancarai mengaku kesulitan mengakses materi-materi online yang diberikan guru, dan hanya $18 \%$ yang berhasil hadir di setiap kelas online untuk mata pelajaran MIPA. Mayoritas peserta didik juga berpendapat bahwa kelas online sulit diikuti dengan beberapa alasan seperti jaringan internet sering lag (40\%), suasana kelas online membosankan (25\%), penjelasan guru sukar dipahami karena kurang interaktif (30\%), dan lainlain $(5 \%)$. Berdasarkan pemaparan di atas, maka peneliti tertarik untuk meneliti tentang pengaurh sikap dan kemampuan akses internet terhadap hasil belajar kimia peserta didik di SMA Negeri 6 Kupang selama pembelajaran daring (online). Kimia dipilih sebagai subjek pelajaran penelitian karena kimia merupakan salah satu mata pelajaran MIPA yang cukup rendah pencapaiannya oleh rata-rata peserta didik di SMA Negeri 6 Kupang (capaian nilai di bawah 60).

\section{METODE PENELITIAN}

Penelitian ini dilakukan di SMA Negeri 6 Kupang, yang beralamat di Jl. H.R Koroh, Sikumana, Kota Kupang. Penelitian dilaksanakan selama 1 (satu) bulan, yakni selama bulan September 2021. Populasi dalam penelitian ini yakni seluruh siswa SMA Negeri 6 Kupang, sedangkan sampel dalam penelitian ini sebanyak 104 orang yang berasal dari Kelas XII Jurusan MIPA. Pemilihan sampel menggunakan metode purposive sampling, dengan perhitungan rumus sampel Yamane. Penelitian ini merupakan penelitian kuantitatif, menggunakan metode survei. Sedangkan desain penelitiannya dapat digambarkan sebagai berikut:

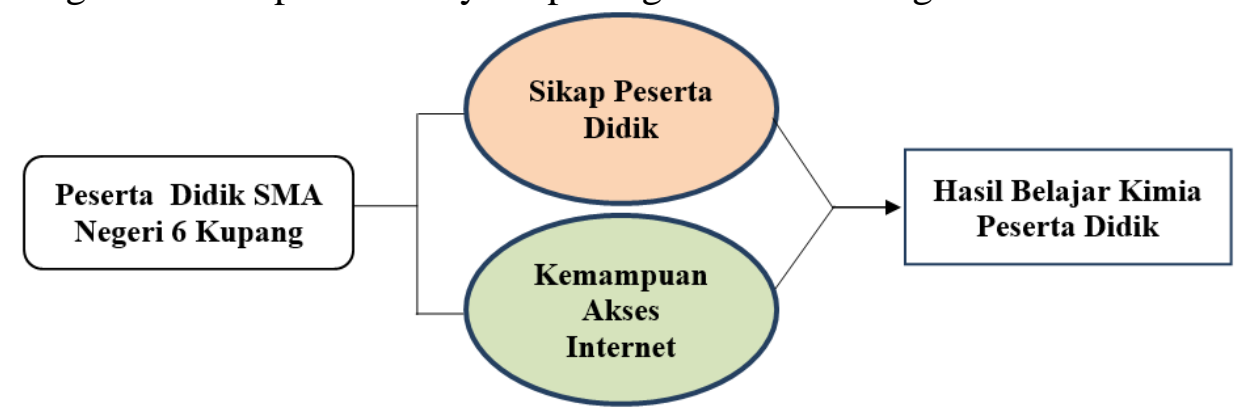

Gambar 1. Desain Penelitian 


\section{HASIL DAN PEMBAHASAN}

\section{Hasil}

1. Hasil belajar kimia, sikap, dan kemampuan peserta didik mengakses internet

Hasil belajar kimia, sikap, dan kemampuan peserta didik mengakses internet untuk kebutuhan pembelajaran online peserta didik SMA Negeri 6 Kupang terhadap mata pelajaran kimia selama pandemi Covid-19 disajikan dalam tabel berikut :

Tabel 1. Distribusi Silang Hasil Belajar dan Sikap Peserta Didik SMA Negeri 6 Kupang Selama Pandemi Covid-19

\begin{tabular}{|c|l|c|c|c|}
\hline \multicolumn{4}{|c|}{ Cosil belajar * sikap Crosstabulation } \\
\hline \multicolumn{4}{|c|}{ Count } \\
\cline { 2 - 4 } \multicolumn{2}{|c|}{ sikap } \\
\cline { 2 - 4 } \multicolumn{2}{|c|}{ kurang baik } & baik & Total \\
\hline hasil belajar & kurang baik & 49 & 2 & 51 \\
\cline { 2 - 5 } & baik & 10 & 43 & 53 \\
\hline \multicolumn{2}{|c|}{ Total } & 59 & 45 & 104 \\
\hline
\end{tabular}

Berdasarkandi atas, bisa dilihat bahwa dari 104 peserta didik, 51 orang memiliki hasil belajar yang kurang baik (49,03\%), dan terdapat 53\% orang dengan hasil belajar baik. Hasil belajar di sini mengacu pada standar kelulusan nilai Kimia yakni di atas 80. Sementara rata-rata peserta didik di SMA Negeri 6 Kupang memiliki sikap yang kurang baik terhadap mata pelajaran kimia, yaitu sebesar $56,73 \%$.

Tabel 1 juga menunjukkan bahwa rata-rata peserta didik di SMA Negeri 6 Kupang memiliki hasil belajar Kimia dengan kategori baik jumlahnya hampir 50:50 dibanding dengan yang kurang baik. Dari 53\% peserta didik dengan kategori hasil belajar baik, 45 orang $(81 \%)$ memiliki sikap baik, sementara peserta didik dengan kategori hasil belajar kurang baik, 96\% memiliki sikap kurang baik. Hal ini menunjukkan trend bahwa peserta didik dengan sikap baik, cenderung mendapatkan nilai yang baik, begitupun sebaliknya.

Tabel 2. Distribusi Silang Hasil Belajar dan Kemampuan Mengakses Internet Peserta Didik SMANegeri 6 Kupang Selama Pandemi Covid-19

\begin{tabular}{|c|c|c|c|c|}
\hline \multicolumn{5}{|c|}{ hasil belajar * internet Crosstabulation } \\
\hline \multicolumn{5}{|c|}{ Count } \\
\hline & & \multicolumn{2}{|c|}{ internet } & \multirow[b]{2}{*}{ Total } \\
\hline & & kesulitan internet & $\begin{array}{c}\text { tidak kesulitan } \\
\text { internet }\end{array}$ & \\
\hline \multirow[t]{2}{*}{ hasil belajar } & $\begin{array}{l}\text { kurang } \\
\text { baik }\end{array}$ & 47 & & 51 \\
\hline & Baik & 7 & 4( & 53 \\
\hline \multicolumn{2}{|l|}{ Total } & 54 & 5( & 104 \\
\hline
\end{tabular}

Berdasarkan tabel 2 di atas, bisa dilihat bahwa dari 104 peserta didik, 54 orang memiliki kesulitan mengakses internet, atau sebanyak 51,92\%. Selain itu bisa dilihat bahwa dari 51 peserta didik yang memiliki hasil belajar kurang baik (49,03\%), 92,15\% peserta tersebut kesulitan mengakses internet. Sementara itu, dari 53\% peserta didik dengan kategori hasil belajar baik, hanya ada 7 orang $(13,20 \%)$ orang yang kesulitan mengakses internet. Hal ini menunjukkan bahwa peserta didik dengan kemampuan akses internet yang baik (tidak mengalami kesulitan kuota dan sinyal) cenderung memiliki nilai yang lebih baik dibanding peserta didik yang mengalami kesulitan akses internet. 
2. Analisa hubungan antara sikap, kemampuan akses internet, dan hasil belajar peserta didik

Hasil analisa hubungan antara sikap, kemampuan akses internet, dan hasil belajar peserta didik SMA Negeri 6 Kupang selama pandemik Covid-19 disajikan dalam tabel berikut.

Tabel 3. Hasil Uji Analisa Regresi Berganda Untuk Uji Pengaruh Sikap dan Kemampuan Mengakses Internet terhadap Hasil Belajar Kimia Peserta Didik SMA Negeri 6 Kupang Selama Pandemi Covid-19

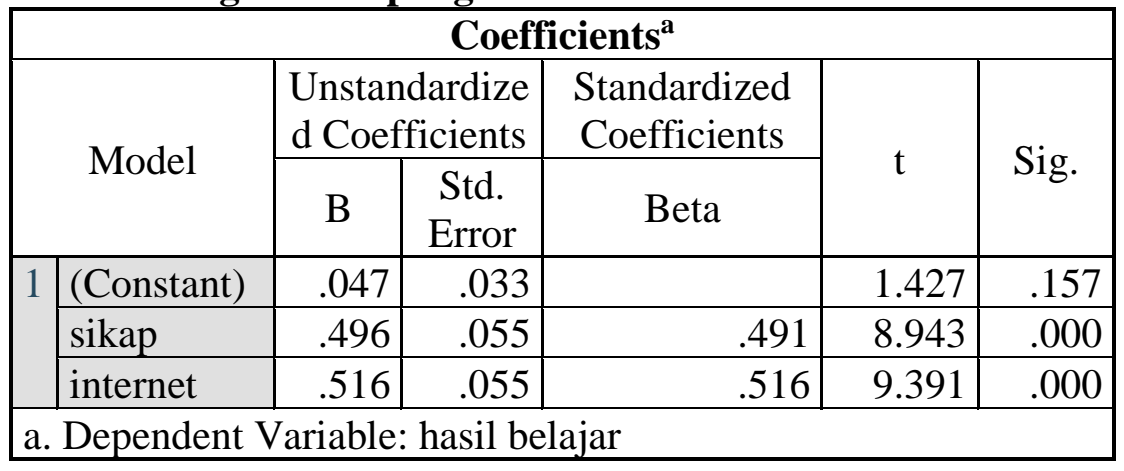

Berdasarkan tabel 2 di atas, bisa dilihat bahwa nilai konstanta variabel Hasil Belajar yaitu 0,047. Artinya bahwa jika variable sikap dan kemampuan akses internet sebagai variable bebas $(\mathrm{X} 1, \mathrm{X} 2)$ bernilai sama dengan 0 , maka hasil belajar peserta didik SMANegeri 6 Kupang adalah sebesar 0,047. Jika terjadi peningkatan sikap peserta didik terhadap pelajaran Kimia sebesar $1 \%$, maka hasil belajar akan meningkat sebesar $49 \%$. Sebaliknya jika terjadi penurunan sikap sebanyak $1 \%$ maka akan terjadi penurunan hasil belajar sebesar $49 \%$. Sementara itu, jika terjadi peningkatan $1 \%$ untuk variable kemampuan akses internet, maka hasil belajar akan meningkat sebesar $51 \%$, begitupun sebaliknya. Untuk nilai signifikansi lebih kecil dari 0,05 yang mana hal ini menunjukkan bahwa terdapat pengaruh yang signifikan/nyata antara sikap dan kemampuan akses internet terhadap hasil belajar Kimia peserta didik SMA Negeri 6 Kupang di era pandemi Covid-19.

Berdasarkan tabel 2 di atas juga memberi kesimpulan bahwa jika variabel sikap dan kemampuan akses internet peserta didik adalah 0, maka hasil belajar peserta didik akan bernilai 0,047 . Jika variabel sikap peserta didik terhadap pelajaran kimia adalah tetap/tidak berubah, maka maka setiap kenaikan $1 \%$ kemampuan akses internet akan berpengaruh sebanyak 51,6\% terhadap hasil belajar kimia peserta didik. Sementara setiap 1\% kenaikan variabel sikap dan kemampuan akses internet tetap/tidak berubah, maka hasil belajar kimia peserta didik akan berpengaruh sebanyak $49,6 \%$.

Hasil uji Annova untuk melihat pengaruh sikap dan kemampuan akses internet terhadap hasil belajar Kimia peserta didik SMA Negeri 6 Kupang selama pandemi Covid19 bisa dilihatpada tabel3 di bawah ini.

Tabel 3. Hasil Uji Annove Untuk Uji Pengaruh Sikap dan Kemampuan Mengakses Internet terhadap Hasil Belajar Kimia Peserta Didik SMANegeri 6 Kupang Selama Pandemi Covid-19

\begin{tabular}{|c|c|c|c|c|c|c|}
\hline \multicolumn{7}{|c|}{$\mathrm{ANOVA}^{\mathrm{a}}$} \\
\hline \multicolumn{2}{|c|}{ Model } & $\begin{array}{c}\text { Sum of } \\
\text { Squares }\end{array}$ & $\mathrm{df}$ & $\begin{array}{l}\text { Mean } \\
\text { Square }\end{array}$ & $\mathrm{F}$ & Sig. \\
\hline \multirow[t]{3}{*}{1} & Regression & 20.536 & 2 & 10.268 & 190.155 & $.000^{\mathrm{b}}$ \\
\hline & Residual & 5.454 & 101 & .054 & & \\
\hline & Total & 25.990 & 103 & & & \\
\hline
\end{tabular}


b. Predictors: (Constant), internet, sikap

Untuk hasil uji Annova diperolah nilai sig 0,000 > 0,050, yang berarti terdapat pengaruh yang signifikan dari sikap dan kemampuan akses internet terhadap hasil belajar kimia peserta didik SMANegeri 6 Kupang, dengan presentasi 79\% (nilai R Square yang diperoleh dari uji regresi berganda ini yaitu 0,790).

\section{Pembahasan}

Hasil belajar merupakan tolak ukur keberhasilan siswa setelah menempuh proses belajar. Hasil belajar secara umum dapat dikelompokkan ke dalam tiga ranah yaitu ranah kognitif, afektif, dan psikomotorik. Evaluasi merupakan skala penilaian yang digunakan dalam menentukan hasil yang diperoleh siswa selama kegiatan pembelajaran di sekolah yang berfokus pada nilai siswa dalam proses pembelajaran di sekolah. Nilai tersebut dinilai dari segi kognitif karena guru sering memakainya untuk melihat penguasaan pengetahuan sebagai pencapaian hasil belajar siswa. Hasil belajar merupakan bagian terpenting dalam pembelajaran. Sudjana (2009) mendefinisikan hasil belajar siswa pada hakikatnya adalah perubahan tingkah laku sebagai hasil belajar dalam pengertian yang lebih luas mencakup bidang kognitif, afektif dan psikomotorik. Dimyati (2009) dalam Rosa (2012) juga menyebutkan hasil belajar merupakan hasil dari suatu interaksi tindak belajar dan tindak mengajar.

Dari data penelitian setelah dilakukan analisis korelasi diperoleh koefisien korelasi sebesar 0,790 menunjukkan bahwa ada pengaruh positif dan signifikan antara Sikap pada Mata Pelajaran Kimia dan Kemampuan Akses Internet secara bersama-sama terhadap Hasil Belajar Kimia Peserta Didik dengan besar kontribusi sebesar 79\%. Hasil penelitian ini sejalan dengan penelitian serupa yang dilakukan oleh Ismail (2017) yang menemukan bahwa terdapat pengaruh penggunaan internet terhadap hasil belajar IPS peserta didik kelas X SMK Nurul Huda Sukaraja OKU Timur, dengan pengaruh secara simultan penggunaan internet sebagai variabel bebas sebesar $87 \%$. Hasil ini menjadi bukti bahwa variabel tersebut mempunyai pengaruh yang cukup nyata terhadap hasil belajar peserta didik. Jika dibandingkan dengan Kimia, Pelajaran IPS tidak memiliki banyak rumus dan permodelan, namun peran internet tetap penting dan memiliki impact yang nyata terhadap hasil belajar.

Mulyana (2006) menjelaskan bahwa prestasi belajar merupakan hasil interaksi berbagai faktor, baik pribadi maupun lingkungan. Sikap pada Mata Pelajaran Kimia adalah faktor yang berasal dari pribadi masing-masing peserta didik yang merupakan penggerak dalam usaha meraih prestasi yang tinggi. Sikap terhadap belajar merupakan faktor penting yang menentukan keberhasilan proses belajar mengajar. Sikap yang positif pada pelajaran kimia akan meningkatkan prestasi belajar kimia. Sebaliknya Sikap yang negatif pada pelajaran kimia akan menghambat peserta didik untuk memperoleh prestasi yang baik. Hasil penelitian Novrita Mulya Rosa (2015) menemukan kesimpulan bahwa sikap pada mata pelajaran Kimia dan konsep diri berpengaruh terhadap prestasi belajar kimia siswa kelas X SMA swasta di kecamatan Cilandak Jakarta Selatan, dengan kontribusi pengaruh sebesar 77,1\%. Variabel sikap sendiri memiliki besaran pengaruh sebesar 39\%. Hal ini mendukung hasil penelitian pengaruh sikap terhadap hasil belajar Kimia peserta didik SMAN 06 Kupang yang menunjukkan bahwa hasil belajar Kimia meningkat 49,6\% untuk setiap kenaikan presentasi variabel sikap.

Sikap peserta didik pada mata pelajaran Kimia dapat diketahui dari cara peserta didik bereaksi atau memberikan respon terhadap kimia ketika kegiatan pembelajaran berlangsung, baik di dalam kelas maupun di luar kelas. Sikap pada umumnya mempunyai unsur motivasi dan emosi. Sikap dapat bersifat positif dengan adanya kecenderungan tindakan mendekati, menyenangi dan mengharapkan objek tertentu. Sikap dapat pula bersifat negatif dengan menjauhi, menghindari, membenci dan tidak menyukai objek tertentu. Sikap peserta didik pada mata pelajaran kimia merupakan salah satu faktor penentu keberhasilan peserta didik menguasai dan memahami materi pelajaran kimia. 


\section{SCIENCE : Jurnal Inovasi Pendidikan Matematika dan IPA Vol. 1 No. 3 November 2021 e-ISSN : 2797-1031 | p-ISSN : 2797-0744}

Ngalim Purwanto (2007) dalam Ismail, Khafid Ismail (2017) menjelaskan sikap sebagai suatu cara bereaksi terhadap suatu perangsang. Dalam pengertian ini sikap merupakan kecenderungan seseorang untuk bereaksi dengan cara tertentu terhadap suatu obyek atau situasi yang dihadapi sehingga sikap dapat bersifat positif dan ada pula yang bersifat negatif. Sikap positif adalah kecenderungan tindakan untuk mendekati, menyenangi, mengharapkan obyekobyek tertentu. Sedangkan sikap negatif adalah kecenderungan untuk menjauhi, menghindari, membenci, tidak menyukai obyek-obyek tertentu. Peserta didik yang memiliki sikap positif, ia akan menganggap kimia itu sebagai pelajaran yang mudah dan asyik untuk dipelajari. Ia akan semangat dan selalu memperhatikan penjelasan dari guru ketika pembelajaran berlangsung. Selain itu peserta didik yang memiliki sikap positif terhadap kimia akan selalu belajar atas kesadaran sendiri bukan hanya karena ada tugas ataupun ketika akan ujian saja, sehingga prestasi belajarnya pun akan baik. Semakin positif sikap peserta didik pada pelajaran kimia akan semakin mudah pula bagi peserta didik untuk menguasai materi kimia yang disampaikan dalam proses pembelajaran di sekolah yang ditunjukkan dengan prestasi belajar kimia yang tinggi. Sebaliknya peserta didik yang memiliki sikap negatif terhadap kimia, ia akan menganggap kimia itu sebagai pelajaran yang sulit dan tidak menarik, ia juga akan malas dan merasa terpaksa dalam belajar kimia, sehingga hasil belajarnya kurang baik dan tidak memuaskan. Semakin negatif sikap peserta didik untuk mempelajari kimia maka akan berdampak pada rendahnya prestasi belajar kimia.

Faktor lainnya yaitu kemampuan akses internet peserta didik dalam mengikuti pembelajaran online. Dalam penelitian ini terungkap bahwa pengaruh kemampuan akses internet lebih besar dari sikap peserta didik terkait mata pelajaran Kimia terhadap hasil belajar siswa, dengan presentasi sebesar $51,60 \%$. Semakin baik kemampuan peserta didik dalam mengakses internet, dalam arti tidak kesulitan sinyal dan kuota internet, maka semakin besar pengaruhnya terhadap hasil belajar Kimia peserta didik. Hal ini sejalan dengan penelitian hasil penelitian Dwi Rani Pratiwi (2012) yang berjudul Pengaruh Pemanfaatan Internet terhadap Hasil Belajar Siswa Kelas XI pada Mata Pelajaran Teknologi Informasi dan Komunikasi di SMA Negeri 1 Pengasih. Hasil penelitian tersebut menunjukkan bahwa hasil belajar siswa sesudah perlakuan pembelajaran kelas eksperimen yang menggunakan media pemanfaatan internet hasilnya jauh lebih tinggi dibanding kelas kontrol yang tanpa menggunakan pemanfaatan internet, serta terjadi peningkatan hasil belajar yang signifikan antara sebelum dan sesudah perlakuan. Berdasarkan hasil penelitian tersebut dapat ditarik kesimpulan bahwa pemanfaatan internet berpengaruh terhadap hasil belajar siswa.

Kendala di SMA Negeri 6 Kupang yaitu masih cukup banyak siswa yang mengalami kesulitan akses internet, yaitu sebanyak 51,92\% atau sebanyak 54 dari 104 orang. Hal ini berpengaruh nyata pada hasil belajar Kimia, di mana 92,16\% dari 54 orang tersebut memiliki hasil belajar yang kurang baik. Ahira (2011) menjelaskan bahwa penggunaan internet sebagai media belajar sangat membantu para akademisi dalam belajar. Oetomo (2002) menyatakan bahwa era internet terus bergulir sehingga makin banyak orang terdorong untuk mengakses internet baik untuk keperluan bisnis, surat menyurat maupun pendidikan, mulai dari anak-anak hingga orang dewasa. Berdasarkan uraian ini jelas bahwa kemampuan akses internet siswa akan sangat bermanfaat bagi proses belajar mengajar di sekolah, terutama di era pandemi di mana semua pembelajaran mulai digitalisasi.

SMANegeri 6 Kupang memiliki peserta didik yang mayoritasnya berasal dari keluarga tidak mampu. Hal ini dibuktikan dengan $80 \%$ orang tua/wali peserta didik memiliki pendapatan kurang dari 2 juta/bulan, dan 65\% adalah buruh, pedagang mikro, dan petani (Data Dapodik SMANegeri 6 Kupang, 2020). Latar belakang keluarga yang kurang mampu memberi gambaran bahwa kemampuan akses internet peserta didik secara rata-rata yang rendah (54 orang dari 104 siswa). Dengan presentasi ini tentu berpengaruh pada hasil belajar Kimia siswa selama masa pandemic. Pembelajaran online membutuhkan tidak hanya sinyal dan perangkat (Hp/laptop) yang bagus, namun juga kuota internet. Akses belajar via google meet untuk 1,5 jam memakan biaya kuota internet sekitar 700 MB (Data Survei Siswa SMA Negeri 6 Kupang, 


\section{SCIENCE : Jurnal Inovasi Pendidikan Matematika dan IPA Vol. 1 No. 3 November 2021 e-ISSN : 2797-1031 | p-ISSN : 2797-0744}

2020). Jika dalam sehari ada 3 pelajaran yang diselenggarakan online, maka total kuota yang dibutuhkan adalah 2,1GB/hari. Jika dikonversikan ke nominal rupiah, setiap GB membutuhkan sekitar 15ribu. Itu berarti peserta didik butuh setidaknya Rp 31.500 per hari untuk belajar online. Bisa juga berlangganan paket kuota internet bulanan, namun biayanya cukup besar untuk sekali pengeluaran (kisaran 200-250ribu untuk 30GB/30 hari). Kisaran biaya ini adalah untuk provider yang paling stabil di NTT, yaitu Telkomsel. Sementara pilihan paket wifi dan provider lain yang lebih murah jarang diakses oleh peserta didik.

Peserta didik SMANegeri 6 Kupang memiliki kendala akses internet yang cukup serius. Presentasi kehadiran peserta didik dalam pembelajaran online kurang dari $30 \%$ (Data Kurikulum SMANegeri 6 Kupang, 2020). Presentasi kehadiran yang rendah ini memperkuat hasil penelitian bahwa hanya 50 dari 104 peserta didik yang mampu mengakses internet tanpa kesulitan sinyal dan kuota. Sistem pembelajaran daring yang dilaksanakan kurang lebih 4 semester di SMANegeri 6 Kupang memberi dampak nyata pada rendahnya hasil belajar Kimia siswa. Kuat dugaan bahwa mata pelajaran MIPA yang lain juga mengalami kasus serupa. Jika hal ini tidak mendapat perhatian serius dari pihak sekolah dan juga pemerintah di lingkup Kemendikbud, maka besar kemungkinan bahwa peserta didik akan semakin tertinggal dalam akses ilmu pengetahuan lewat KBM online sekolah.

Sikap peserta didik yang rendah dan didukung oleh ketidakmampuan akses internet akan berpengaruh negative pada hasil belajar Kimia. Kimia sebagai mata pelajaran eksata yang sarat dengan rumus dan permodelan, membutuhkan banyak fokus dan latihan soal agar peserta didik mahir dan memahami setiap topic pelajaran dengan baik. Azhar (2015) memberi penjelasan bahwa dengan pemberlakuan pembelajaran online, semua latihan soal dan penjelasan dalam sebuah presentasi harus dibuat menarik secara visual. Jika dikaitkan dengan konsep pembelajaran dengan menggunakan materi audio visual (video) maka dibutuhkan lebih banyak kuota internet untuk mengaksesnya. Hal ini bisa mempersulit peserta didik yang memiliki kesulitan akses internet. Peserta didik akan cenderung lambat memahami materi, bahkan kehilangan akses untuk proses belajar yang interaktif jika saat proses pelajaran online berlangsung.

Semua fenomena ini merupakan tantangan tersendiri bagi orang tua, pihak sekolah, dan terutama bagi peserta didik itu sendiri. Orang tua perlu biaya ekstra untuk menyediakan kuota internet, karena biaya pulsa data tidak murah, terutama di wilayah NTT. Selain itu, orang tua tidak boleh abai dan membiarkan anak berselancar internet sendiri selama 24 jam, karena ada peluang anak tidak menggunakan kuota internet hanya untuk proses belajar daring, melainkan dipakai untuk hiburan seperti main game online, dan atau menonton konten-konten yang tidak berhubungan dengan pelajaran. Sekolah di lain sisi penting untuk mengevaluasi partisipasi dan hasil belajar peserta didik (siswa) dalam proses belajar daring. Perlu ada strategi untuk bagaimana meningkatkan hasil belajar siswa, tanpa memberatkan orang tua dan siswa untuk mengakses internet dengan biaya tinggi. Siswa sebagai peserta didik juga harus menjadi subjek pendidikan yang memiliki minat belajar tinggi sehingga mampu mengatasi berbagai masalah dalam pembelajaran online, dan yang lebih penting yaitu, mampu mendisiplinkan diri sendiri untuk bisa memanfaatkan kuota internet sebaik mungkin untuk kepentingan belajar online, tanpa terpengaruh untuk menggunakan internet secara negatif.

Guru mata pelajaran Kimia harus memikirkan metode pembelajaran yang sesuai dengan kasus-kasus seperti ini. Perlu ada inovasi dan modifikasi terarah bagi peserta didik untuk bagaimana tetap bisa mendapat pelajaran dan penjelasan konkrit terkait topic-topik Kimia, tanpa memaksakan keadaaan peserta didik untuk selalu memiliki akses internet. Solusi yang bisa ditawarkan peneliti ada 4, yaitu:

1. Buatkan materi pelajaran yang ringkas namun semenarik mungkin, dan kirimkan sebelum pelajaran berlangsung. Hal ini memberi kesempatan peserta didik untuk mendownload materi terlebih dahulu, dan peserta didik yang kesulitan mengakses internet, bisa mengcopy file materi dari salah satu teman yang sudah mendownload secara manual (copy 
langsung dari flash disk atau Bluetooth. Hal ini akan menghemat kuota internet, sekaligus memberi gambaran awal materi kepada peserta didik sehingga bisa dipelajari.

2. Saat pembelajaran online berlangsung, gunakan waktu seefektif mungkin, dan tidak berteletele. Lebih banyak berikan contoh soal yang berbeda-beda sesuai topic, dan kirimkan file contoh soal tambahan yang bisa didownload ke depan;

3. Untuk pengiriman tugas, gunakan aplikasi pengiriman pesan gratis seperti FB mode gratis, dan atau memberikan titik kumpul di beberapa peserta didik yang memiliki kemampuan akses internet yang baik. Peserta didik bisa mengumpulkan tugas ke orang-orang yang sudah ditunjuk guru sehingga mengurangi keharusan untuk menggunakan internet orang per orang;

4. Buat kelompok belajar yang bisa mengakomodir peserta didik yang mengalami kesulitan akses internet, dengan peserta didik yang bisa mengakses internet tanpa gangguan. Jika dimungkinkan, gunakan wifi sekolah untuk pembelajaran kelompok dengan system shift.Hindari kelas pembelajaran online di waktu yang kurang kondusif seperti terlalu pagi atau malam yang membuat peserta didik kesulitan keluar rumah untuk akses internet

Rosa (2015) dalam penelitiannya juga menyarankan agar guru menggugah sikap positif peserta didik untuk mengetahui dan memahami kimia serta mengerti akan manfaatnya. Kimia sebagai bidang studi membutuhkan kekuatan mental dan kemampuan abstrak dan berpikir kritis, untuk dapat memahami dan menguasai materi kimia dengan baik, dari kondisi tersebut disarankan agar sekolah dapat menyesuaikan tingkat kesulitan materi kimia dengan kemampuan peserta didik. Penulis berkeyakinan bahwa dengan memperhatikan saran-saran dan solusi di atas maka masalah rendahnya hasil belajar Kimia yang dipengaruhi oleh faktor sikap dan kemampuan akses internet peserta didik bisa berangsur diperbaiki dan pendidikan di Indonesia secara umum tidak tergerus oleh impact negatif pandemi Covid 19.

\section{KESIMPULAN}

Berdasarkan data hasil penelitian dan pembahasan, maka dapat disimpulkan bahwa: (1) Terdapat pengaruh sikap dan kemampuan akses internet secara bersama-sama dan signifikan terhadap hasil belajar kimia peserta didik SMANegeri 6 Kupang sebesar 79\%, (2) Terdapat pengaruh sikap pada pelajaran kimia terhadap hasil belajar kimia peserta didik kelas SMANegeri 6 Kupang sebesar 41,60\%, (3) Terdapat pengaruh kemampuan akses internet terhadap hasil belajar kimia peserta didik kelas SMANegeri 6 Kupang sebesar 51,60\%, (4) Guru dan orang tua diharapkan mampu melakukan evaluasi berkala dan memberikan stimulus yang positif pada peserta didik agar bisa mengembangkan sikap positif terhadap pelajaran Kimia, sementara peserta didik atau siswa sendiri harus terus memiliki motivasi dan disipilin diri yang baik agar bisa memanfaatkan akses internet semaksimal mungkin untuk pembelajaran online, (5) Guru mata pelajaran Kimia perlu berupaya meningkatkan keaktifan peserta didik terhadap pelajaran Kimia dengan memperhatikan keterbatasan peserta didik ddalam mengakses internet. Upaya yang dimaksud bisa berupa kerja kelompok atau presentasi kelompok yang sebelumnya sudah direkam dan ditonton bisa offline, serta memberikan materi-materi pembelajaran yang padat namun tidak menguras kuota internet saat pembelajaran daring dilakukan, misalnya meminimalisir penggunaan video streaming. Serta menghindari kegiatan belajar daring di waktu yang tidak kondusif (terlalu malam atau terlalu pagi).

\section{DAFTAR PUSTAKA}

Ahira, Anne (2011). Pengaruh Internet terhadap Prestasi Belajar Siswa. Diambil dari http://anneahira.com. Diakses tanggal 18 Oktober 2021

Ahmad Rivai, Nana Sudjana. (2009). Media Pengajaran. Sinar Baru Algesindo. Bandung Ahmadi, dan Hermawan. (2013). E-Bussines \& E-Commerce. Andi. Yogyakarta.

Arikunto, Suharsimi (2013). Prosedur Penelitian Suatu Pendekatan Praktik. Rineka Cipta. Jakarta

Arsyad, Azhar (2015). Media Pembelajaran. Raja grafindo Persada. Jakarta. 
Fauzi, R. (2010). Pengaruh Internet Terhadap Prestasi Belajar IPS Sejarah Siswa Kelas X Semester II SMA Negeri 1 Bandar Kabupaten Batang Tahun Ajaran 2009/2010. Skripsi. Universitas Negeri Semarang. Semarang

Ismail, Khafid. (2017). Pengaruh Penggunaan Internet Terhadap Hasil Belajar IPS Peserta Didik Kelas X SMK Nurul Huda Sukaraja Oku Timur. Disertasi. Universitas Negeri Semarang. Semarang

Mareta, R. (2012). Pengaruh Penggunaan Internet Sebagai Media Belajar Terhadap Prestasi Belajar Mahasiswa. Skripsi. Universitas Negeri Yogyakarta. Yogyakarta

Mulya Rosa, Novrita. (2015). Pengaruh Sikap Pada Mata Pelajaran Kimia dan Konsep Diri terhadap Prestasi Belajar Kimia. Universitas Indraprasta PGRI Jakarta. Jakarta

Mulyana E. 2006. Implementasi Kurikulum 2004: Panduan Belajar KBK. Remaja Rosdakarya. Bandung

Oetomo. Budi (2002). e-Education (Konsep, Teknologi dan Aplikasi Internet Pendidikan). Andi. Yogyakarta

Pratiwi, Dwi Rani, (2012). Pengaruh Pemanfaatn Internet terhadap Hasil Belajar Siswa Kelas XI pada Mata Pelajaran Teknologi Informasi dan Komunikasi di SMA Negeri 01 Pengasih. Skripsi. Universitas Negeri Yogyakarta (UNY). Yogyakarta.

Sanjaya, W. (2006). Strategi Pembelajaran Berorientasi Standar Proses Pendidikan. Kencana. Bandung

Slameto. (2003). Belajar dan Faktor-faktor yang Mempengaruhinya.Rineka Cipta. Jakarta 